\title{
MODEL IMPLEMENTASI NILAI-NILAI ISLAM DALAM FALSAFAH PI'IL PESENGGIRI MASYARAKAT LAMPUNG DI LABUHAN MARINGGAI
}

\author{
Oleh: \\ Heri Cahyono \\ Novi Rahmawati \\ Universitas Muhammadiyah Metro \\ hericahyono808@gmail.com \\ novirahmawati@gmail.com
}

\begin{abstract}
.
Pesenggiri Pi'il is a philosophy of life that is used as a reference for the people of Lampung from generation to generation because of the values contained therein that can have an impact on community life relationships. However, in the current era er pi'il pesenggiri philosophy has begun to erode even forgotten, so that many people do not know and understand the true meaning of pesenggiri pi'il. The results of the study can be known Islamic values in the Pesenggiri Pi'il Philosophy through its elements namely adek nickname elements there are leadership values. The element of nyimah is the value of friendship, the value of courtesy, and the value of mutual respect. The blurring element is social values and intellectual values. And the sakai samabaian element has mutual values, and ta'wun values. The implementation of the Pesenggiri Pi'il Life Philosophy in Maringgai Village is still preserved.
\end{abstract}

\section{Keywords: Values, Islam, Pi'il Penengiri}

\begin{abstract}
Abstrak.
Pi'il Pesenggiri merupakan falsafah hidup yang dijadikan acuan bagi masyarakat Lampung secara turun-temurun karena nilai-nilai yang terkandung didalamnya yang dapat berdampak pada hubungan kehidupan bermasyarakat. Namun, pada er modern sekarang ini falsafah pi'il pesenggiri sudah mulai terkikis bahkan dilupakan, sehingga banyak masyarakat yang tidak mengetahui dan mengerti makna pi'il pesenggiri yang sebenarnya. Hasil dari penelitian dapat diketahui nilai-nilai Islam pada Falsafah Pi'il Pesenggiri melalui unsur-unsurnya yaitu unsur juluk adek terdapat nilai kepemimpinan. Unsur nemui nyimah terdapat nilai silaturahim, nilai sopan santun, dan nilai saling menghormati. Unsur nengah nyepur terdapat nilaisosial dan nilai intelektual. Dan unsur sakai samabaian terdapat nilai gotong-royong, dan nilai ta'wun. Implementasi Falsafah Hidup Pi'il Pesenggiri di Desa Maringgai masih dilestarikan, hal ini dapat dilihat dalam acara adat perkawinan, kegiatan bertamu dalam sehari-hari,
\end{abstract}


menjau, pengajian, serta gotong royong membersihkan jalan dan masjid.

\section{Kata kunci : Nilai, Islam, Pi’ilPesenggiri}

\section{A. PENDAHULUAN}

Islam adalah agama yang diyakini dan dipahami sebagai ketentuan dan aturan (aqidah wa alsyari'ah) yang bersumber dari Allah Subhanahu Wata'ala yang dibawa oleh Nabi Muhammad Shalallahu 'Alaihi Wasalam kepada seluruh umat manusia sebagai pedoman hidup baik dalam politik, ekonomi, sosial dan budaya. Menurut Deden Sumpena "Islam sebagai agama yang universal sangat menghargai akan adanya budaya yang ada pada suatu masyarakat, sehingga kehadiran Islam ditengah-tengah masyarakat tidak bertentangan, melainkan Islam dekat dengan kehidupan masyarakat. Disinilah sebenarnya bagaimana Islam mampu membuktikan dirinya sebagai ajaran yang flexsibel didalam memahami kondisi kehidupan suatu masyarakat". ${ }^{1}$

Hal ini pun terjadi di Indonesia, dimana Islam yang ada di Indonesia merupakan hasil dari proses dakwah yang dilaksanakan secara culturalmelalui beberapa jalur salah satunya adalah jalur perdagangan. Para pedagang yang membawa dan menyebarkan agama Islam di Indonesia adalah para pedagang dari Gujarat India yang tidak fanatik,sehingga Islam di Indonesia mampu berkembang dan

${ }^{1}$ Deden Sumpena, Islam dan Budaya Lokal: Kajian Terhadap Interelasi Islam dan Budaya Sunda, Bandung: UIN Sunan Gunung Djati, Jurnal Ilmu Dakwah Vol. 6 No. 19, h.107 menyebar secara damai, penuh toleran, dan dalam waktu yang cukup singkat. ${ }^{2}$ Indonesia merupakan suatu kepulauan yang memiliki suku bangsa yang beragam, suku bangsa ini tersebar diseluruh provinsi di Indonesia mulai Sabang sampai Marauke. Dengan keanekaragaman suku ini, Indonesia memiliki keunikanadat, budaya, kepercayaan,keindahan alam, dan cerita sejarah. $^{3}$

Lampung merupakan suatu provinsi yang ada di Indonesia terletak di ujung selatan Pulau Sumatera dan merupakan pintu gerbang utama menuju pulau Sumatera dari Pulau Jawa. ${ }^{4}$ Ada beraneka suku yang berdiam di Lampung antara lain suku Lampung, Jawa, Palembang, Sunda, Jambi, Padang, Bengkulu, Aceh dan lain-lain. ${ }^{5}$ Secara garis besar, masyarakat Lampungterbagi menjadi dua kelompok adat besar yaituadat Lampung Pepadun dan adat Lampung Saibatin. Masyarakatadat Pepadun dikenal dengan nilai-nilai demokrasinya, artinya siapa saja dapat memiliki status sosial.Sedangkan

${ }^{2} \mathrm{~A}$. Daliman, Islamisasi dan Perkembangan Kerajaan-kerajaan Islam di Indonesia, Yogyakarta: Ombak.

${ }^{3}$ Agus Joko Pitoyo, Hari Tri Wahyudi, Dinamika Perkembangan Etnis di Indonesia dalam Konteks Persatuan Negara, (Yogyakarta: Fakultas Geografi UGM Vol. 25 No. 1, 2017), h.65

${ }^{4}$ Firman Sujadi, Lampung Sai Bumi Ruwa Jurai, (Jakarta: Cita Insan Madani, 2013), h. 1

${ }^{5}$ Ibid, h. 22 
masyarakat Adat Saibatin kental dengan nilai-nilai aristokrasinya, yaitu orang-orang yang mempunyai status sosial hanya bisa didapat dari keturunan ${ }^{6}$

Adat istiadat yang hidup dimasyarakat Lampung tidak murni lahir dari masyarakat itu sendiri, melainkan melalui proses dialog panjang antar berbagai budaya.Meskipun agama Hindu dan Budha telah datang terlebih dahulu dan mewarnai kebudayaan setempat,tetapi setelah datangnya agama Islam maka pengaruh Islam ini cukup kuat bagi masyarakat Lampungsendiri. ${ }^{7} \quad$ Islam masuk ke daerah Lampung pada abad ke-1, melalui tiga arah, yaitu daerah Minangkabau, memasuki dataran Belalau. Daerah Palembang, memasuki daerah Komering. Dan daerah banten, memasuki daerah Labuhan Maringgai.

Munculnya Islam di Lampung, menjadikan ajaranIslam sebagai salah satu aturan yang diakui keberlakuannya di masyarakat. Meskipun demikian, Islam tidak menghapus tradisi yang sudah ada dimasyarakat tetapi Islam meluruskan adat yang tidak sesuai dengan perintah Allah Subhanahu Wata'ala. Terjadinya interaksi antara agama Islam dan budaya diantaranya dapat dilihat dalam Falsafah Hidup Ulun Lampung.

Falsafah hidup Ulun Lampung dikenal dengan sebutan Pi'il

${ }^{6}$ Op Cit, h. 100

Agama Islam merupakan agama yang dianut oleh sebagian besar masyarakan Ulun Lampung .konon, ulun Lampung pasti beragama islam. Hal ini dibenarkan oleh Bapak Yusuf dalam wawancara pada tanggal November 2019

pesenggiri. Pi'il Pesenggiri adalah falsafah hidup yang tersari dari kitab kuno yaitu kitab Kuntara Rajaniti dan kitab Keterem (larangan). Pi'il pesenggiri merupakan acuan bagi ulun Lampung secara turun menurun dalam berprilaku karena nilai-nilai yang terkandung di dalamnya digunakan sebagai landasan etika sosial, agama, dan moral yang dapat berdampak pada hubungan kehidupan bermasyarakat sehingga memberikan konstribusi dalam pembangunan masyarakat itu sendiri. ${ }^{8}$ Pi'il artinya adalah prinsip, sedangkan Pesenggiri artinya adalah harga diri, identitas atau jatidiri. Pi'il Pesenggiri berarti perasaan malu ketika melakukan perbuatan hina menurut agama serta memilikiharga diri yang kuat.Allah Subhanahu Wata'ala berfirman dalam Al-Qur'an surat AlBaqarah ayat 148 Yang artinya: "Dan bagi tiap-tiap umat ada kiblatnya (sendiri) yang ia menghadap kepadanya. Maka berlomba-lombalah (dalam membuat) kebaikan. di mana saja kamu berada pasti Allah akan mengumpulkan kamu sekalian (pada hari kiamat). Sesungguhnya Allah Maha Kuasa atas segala sesuatu". .

Himyari Yusuf berpendapat bahwa "Unsur-unsur di dalam falsah Pi'il Pesenggiri antara lain Juluk Adek, Nemui Nyimah, Nengah Nyappur, dan Sakai Sambaian. Keempat unsur Pi'il Pesenggiri ini memiliki makna yang

\footnotetext{
${ }^{8}$ Fachruddin, Dkk, Upacara Cangget Agung Aktualisasi Nilai-nilai Budaya Daerah Lampung Bagi Generasi Muda, (Lampung: CV Prinsip Bandar Lampung, 1999), h.13 Departemen RI, Al-Quran dan Terjemahannya, (Jakarta: PUSTAKA ALFATIH, 2009)
} 
sangatluas dan mendalam serta tidak bertentangan dengan ajaran islam. Pi'il Pesenggiri artinya harga diri. Bejuluk adek artinya bernama bergelar. Nemui Nyimah berarti terbuka tangan. Nengah Nyappur berarti aktif dalam bergaul. Sakai Sambaian artinya gotong royong". 10

Dalam era modernisasi sekarang ini, falsafah hidup Ulun Lampung perlahan-lahan mulai dilupakan. Hal ini tidak terlepas dari pengaruh budayabarat dan karakter masyarakat yang suka meniru, serta perkembangan zaman dan tekhnologi yang semakin lama semakin canggih telah meracuni moral akhlak dan tata krama pergaulan masyarakat. Sehingganya tidak sedikit anggota masyarakat tersebut yang salah memaknai Falsafah hidup sendiri, karena dianggap tidak perlu atau sesuatu yang sia-sia, sesuatu yang tidak bernilai dan lain sebagainya.Pandangan semacam ini harus diluruskan, karena dapat membahayakan keseimbangan dan keharmonisan kehidupan masyarakat dan kehidupan mahluk kesemestaan lainnya.

Desa Meringgai adalah salah satu desa yang berada di Kecamatan Labuhan Maringgai Kabupaten Lampung Timur.Desa Meringgai termasuk kedalam suku Lampung Melinting.Dalam sejarah Lampung, desa Maringgai merupakan tempat bersejarah bagi Keratuan Melinting yang mendapat pengaruh langsung dari kesultanan Banten melalui

10 Himyari Yusuf, Nilai-nilai Islam dalam Falsafah Hidup Masyarakat Lampung, Jurnal Studi Agama dan Pemikiran Islam (IAIN Raden Intan Lampung Vol. 10 Nomor 1 Juni 2016), h. 183 perkawinannya dan asal-usul keratuan Melinting merupakan daerah kekuasaan putranya.Karena pengaruh Islam yang dibawa Kesultanan Banten menjadikan daerah Keratuan Melinting khususnya Desa Maringgai semua masyarakatnya beragama Islam.

Masyarakat Desa Maringgai merupakan masyarakat yang masih melestarikan dan mempertahankan budaya Falsafah Pi'il Pesenggiri. Hal ini dapat dilihat dari kerukunan masyarakat dalam kegiatan sehari-hari, seperti gotong royong, perkawinan, dan lain sebagainya, serta masih banyaknya para tokoh adat yang melestarikan kebudayaan Lampung secara turuntemurun sehingga dari latar belakang diatas penulis akan melakukan eksplorasi secara mendalam terkait dengan bagaimana nilai-nilai Islam dalam falsafah hidup pi'il psenggiri dan bagaimana implementasinya pada masyarakat meringgai.

\section{B. METODOLOGI PENELITIAN}

Jenis penelitian ini adalah penelitian lapangan (field research), karena menekankan pada tinjauan langsung di lapangan. Dan sifatpenelitian ini adalah penelitian Deskriptif Kualitatif. Adapun yang dimaksud dengan deskiptif adalah penelitian yang menyajikan secara sama terkait tentang karakter-karakter dari berbagai persoalan obyek penelitian yang ada pada sasaran penelitian. $^{11}$ Berangkat dari analisis yang ada serta permasalahan yang

${ }^{11}$ Kemenag $\quad$ RI, PedomanPenulisanKaryallmiah dan Skripsi, Palembang: Kopertais, h.8 
penulis lakukan untuk mendukung penelitian ini, maka penelitian ini dilaksanakan di Desa Meringgai Kecamatan Labuhan Maringgai Kabupaten Lampung Timur. Adapun metode pengumpulan data dalam penelitian ini adalah wawancara, observasi dan dokumentasi.

\section{PEMBAHASAN}

Kehidupan masyarakat Lampung dapat dilihat dari falsafah hidupnya yaitu Falsafah Hidup Pi'il pesenggiri dan unsur-unsur didalamnya.Pi'il pesenggiri adalah semacam tatanan moral yang merupakan pedoman bersikapdan berperilaku masyarakat Lampung dalam segala aktivitas hidup, yang pada hakikatnya masyarakat Lampung menginginkan hidup sejajar dalam berdampingan. Masyarakat Desa Maringgai lebih mengenal Falsafah Pi'il Pesenggiri dengan sebutan Pi'il, yang artinya gengsi atau malu, malu ketika dirinya melakukan sesuatu yang tidak baik dan melanggar perintah serta larangan Allah Subhanahu Wata'ala. Hal ini sesuai dengan hasil wawancara dengan bapak Ismail selaku Sultan Keratuan Melinting, adapun hasil wawancara tersebut yaitu sebagai berikut: "Pi'il Pesenggiri kalau orang sini bilangnya Pi'il, yang artinya malu.Malu berbuat yang tidak baik, malu ketika mengerjakan sesuatu tidak sesuai dengan yang diajarkan dalam agamanya". 12

\section{a. Juluk Adek}

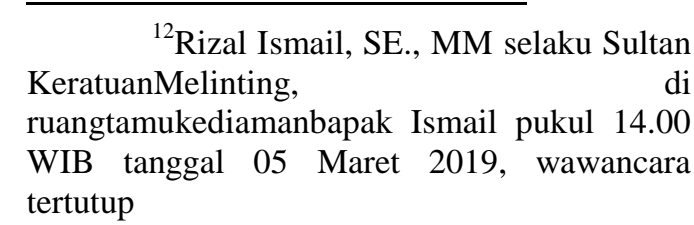

Kegiatan Juluk Adekdi Desa Maringgai dapat dilihat pada acara perkawinan. Desa Maringgai termasuk ke dalam adat keratuan Melinting, padaadat Melinting ini berbeda dengan yang lainnya. Juluk dan adek ini didapatkan ketika sudah menikah, hal ini sesuai dengan yang diungkapkan Zakaria “Juluk dan adek itu adalah pemberian nama setelah ia menikah". ${ }^{13}$ Sesuai dengan adat perkawinan yang berlaku, jika salah satu calon mempelai tidak bersuku lampung maka harus dilampungkan terlebih dahulu, yaitu dengan diangkat menjadi saudara (angkon muwakhi)dan diberi gelar, setelah itu barulah bisa dilakukan perkawinan. Perkawinan menggunakan adat ini biasanya dilakukan pada malam hari, dengan mengumpulkan sultan, Bandar, lid, dan minimal $25 \%$ para penyimbang adat. Setelah akad, Sultan dan para penyimbang melakukan musyawarah pemberian adek kepada si pengantin, setelah disepakati adeknya para penyimbang melakukan tarian yang diiringi talo. ${ }^{14}$ b. Nemui Nyimah

Nemui nyimah artinya bertamu.Bertamu ini dapat dilakukan dalam kegiatan sehari-hariitu ada adab-adabnya, sama seperti adab yang diajarakan Islam. Ketika bertamu ketempat orang lain maka kita harus mengetuk pintu dan mengucapkan salam terlebih dahulu, tidak boleh

${ }^{13}$ Zakaria selaku Pelestari Tari Melinting, di ruang tamu kediaman bapak Zakaria pukul 11.00 WIB tanggal 02 Maret 2019, wawancara tertutup

${ }^{14}$ Hasil Observasi tanggal 26 Maret 2019 
masuk ke rumah orang lain tanpa permisi dan tuan rumah harus menjamu tamu sebaik mungkin. Sultan Keratuan Melinting mengungkapkan bahwa Nemui nyimah itu bertamu, kalau ada tamu kita harus melayani dengan sopan dan dijamu dengan hidangan yang ada, air minum walau hanya air putih ya dihidangkan, kalau ada roti dihidangkan juga. Pokonya dijamu dengan baik". 15

\section{c. Nengah Nyappur}

Kegiatan Nengah nyappur tidak bisa dipisahkan dengan masyarakat Desa Maringgai, hal ini bisa dilihat dari keikutsertaan masyarakat pada setiap acara perkawinan, musyawarah, pengajian dan acaraacara lainnya yang ada di masyarakat.

Menurut Mat Saleh dalam wawancara peneliti mengungkapkan bahwa "Kita itu tidak bisa hidup sendiri. Kita bukan hewan tapi kita manusiayang salingmembutuhkan. Ada acara adat kita ikut, musyawarah, pengajian dan acara-acara lainnya kita ikut. Jangan hanya diam di rumah saja. Karena dengan berpartisipasi dalam setiap acara, kita akan dikenal orang, bisa mensuarakan ide-ide, dan lain sebagainya". 16

\section{d. Sakai Sambaian}

Masyarakat Desa Maringgai sangat aktif dalam bergotong-royong,

${ }^{15}$ Rizal Ismail, SE., MM selaku Sultan Keratuan Melinting, di ruang tamu kediaman bapak Ismail pukul 14.00 WIB tanggal 05 Maret 2019, wawancara tertutup

${ }^{16}$ Mat Saleh selaku Penyimbang di Desa Maringgai, di ruang tamukediaman bapak Mat Saleh pukul 09.00 WIB tanggal 02 Maret 2019, wawancara tertutup hal ini dapat dilihat dari masyarakatnya dalam kerja bakti yang dilakukan setiap hari jum'at. Tidak hanya itu saja, hal ini pun dapat dilihat dalam acara pernikahan, para ibu-ibu datang membawa sembako untuk membantu orang yang memiliki hajat (Menjau). Tidak ketinggalan juga para bapak-bapak yang membantu dalam mendirikan tenda. ${ }^{17}$ Zakaria mengungkapkan bahwa "Contoh dari sakai sembaian itu bisa dilhat pada waktu ada hajatan, orangorang datang membawa beras, gula dan lainnya. Kalau orang sini bilangnya menjau. Bapak-bapaknya juga ada yang bawa bambu, kelapa, drum dan lain sebagainya, pokonya tiba-tiba tarup berdiri aja. ${ }^{18}$

Dari paparan di atas, peneliti membahas bahwa Falsafah Pi'il Pesenggirimerupakan falsafah hidup yang dijadikan acuan bagi masyarakat Lampung secara turun-temurun karena nilai-nilai yang terkandung di dalamnya digunakan sebagai landasan etika sosial, agama, dan moral yang dapat berdampak pada hubungan kehidupan bermasyarakat. Nilai-nilai yang terkandung di dalam falsafah $P{ }^{\prime}$ ' $i l$ Pesenggiritidak terlepas dari pengaruh Islam. Hal ini dapat dilihat dari maknanya yaitu harga diri seseorang tergantung atas kemampuannya untuk berlomba dalam mengarungi kehidupan ini, dan dalam berlomba itu kita hendaklah berposisi sebagai pihak yang

\footnotetext{
${ }^{17}$ Hasil Observasi tanggal 26 Maret 2019

${ }^{18}$ Zakaria selaku Pelestari Tari Melinting, di ruang tamu kediaman bapak Zakaria pukul 11.00 WIB tanggal 02 Maret 2019, wawancara tertutup
} 
lebih banyak bebuat kebaikan. Bersama Pi'il Pesenggiri, Lampung tumbuh dan berkembang dengan memberikan ruang terhormat bagi segenap pendatang. Proyek transmigrasi yang dilaksanakan semenjak masa kolonial dahulu, tidak memiliki hambatan atau gangguan yang berarti apalagi ancaman. Hal tersebut tidak terlepas dari perilaku masyarakat setempat yang sangat dipengaruhi falsafah Pi'il Pesenggiri dan keempat unsurnya. Adapun nilainilai yang terdapat pada falsafah $P{ }^{\prime}{ }^{\prime} i l$ Pesenggiri dan keempat unsur ini adalah sebagai berikut :

Pertama, Nilai kepemimpinan Unsur Juluk Adek terdapat suatu nilai yang luar biasa. Nilai itu adalah nilai kepemimpinan, dimana seseorang yang sudah mendapatkan gelar harus bisa menjadi uswah khasanah dan bertanggung jawab akan gelar (kepemimpinan) yang telah diberikan, baik dalam keluarga maupun masyarakat sekitar. Oleh karena itu, secara esensial, Juluk Adek merupakan ciri orang Lampung dan harus dipertanggung jawabkan secara lahir dan batin, material dan spiritual.

Kedua Nilai Sopan Santun. Sopan santun dalam bertamu merupakan salah satu adab yang diajarkan dalam Islam yang harus diterapkan dalam kehidupan seharihari.Sikap sopan santun ini dalam unsur nemui nyimah sangat penting, karena sopan santun merupakan norma tidak tertulis yang mengatur bagaimana seharusnya kita bersikap atau berperilaku

$\begin{array}{ccr}\text { Ketiga } & \text { Nilai } & \text { Saling } \\ \text { ghormati. } & \text { Nilai } & \text { yang }\end{array}$

terdapatdalam unsur Nemui Nyimahsalah satunya adalah nilai saling menghormati. Islam mengajarkan kita untuk menghormati orang lain dimanapun berada, salah satunya yaitu menghormati orang yang datang berkunjung atau bertamu dengan cara menyuguhkan aneka makanan atau minuman sesuai kemampuan.

Keempat Nilai Intelektual. Islam sangat mendorong manusia untuk menuntut dan menguasai ilmu pengetahuan. Hal ini dijelaskan oleh Allah Subhahanuhu Wata'ala dalam firmannya, yaitu Yang artinya artinya:"Bacalah dengan (menyebut) nama Tuhanmu Yang menciptakan. Dia telah menciptakan manusia dari segumpal darah. Bacalah, dan Tuhanmulah Yang Maha Pemurah. Yang mengajar (manusia) dengan perantaran kalam. Dia mengajar kepada manusia apa yang tidak diketahuinya”. (Al-'Alaq :1-5) Nilai ini terkait keseharusan seseorang memiliki ilmu pengetahuan yang luas dan berkualitas tinggi agar dapat menyalurkan ide-ide dan memecahkan berbagai permasalahan yang ada di tengah-tengah masyarakat. Nilaiinisesuaidengannilai yang ada padaunsurNengahNyappur.

Kelima NilaiSosial. Manusia adalah makhluk sosial yang tidak bisa hidup sendiri. Manusia mebutuhkan bantuanorang laindalam kehidupannya.Hal tersebut secara tidak langsung membentuk rasa kebersamaan pada diri seseorang.Banyak hal yang memunculkan nilai-nilai sosial, diantaranya adalah kegiatan-kegiatan 
yang terdapat pada unsur Nengah Nyappur.

Keenam Nilai Silaturahim. Islam sangat menganjurkan umatnya untuk menjaga silaturahim. Orang yang berkunjung atau bertamu dalam rangka mempererat silaturahim akan mendapatkan keberkahan dari Allah yang berupa tambahan rezeki, kesehatan, dan dipanjangkan umurnya. Sebagaimana tercantum dalam Alquran surat An-nisaayat 1, yang berbunyi yang artinya "Dan bertakwalah kepada Allah yang dengan (mempergunakan) nama-Nya kamu saling meminta satu sama lain, dan (peliharalah) hubungan silaturrahim. Sesungguhnya Allah selalu menjaga dan mengawasi kamu”. Selain itu, silaturahum merupakan tonggak yang mengokohkan banyak hal mulai dari kasih sayang, persatuan, hingga memudahkan seseorang dalam menjalin hubungan. Nilai inilah yang relevan dengan unsur nemui nyimah.

Ketujuh Nilai Gotong-royong. Nilai yang terkandung dalam unsur Nemui Nyimah adalah gotong royong, dimana masyarakat ini secara bersamasama melakukan pekerjaanyang dilandasi rasa sukarela dan kekeluargaan dalam membantu setiap kegiatan masyarakat, baik berupa kerjabakti ataupun acara adat perkawinan.

\section{Kedelapan NilaiTa'awun.}

Manusia sebagai makhluk sosial harus saling tolong-menolong karena manusia saling memebutuhkan satu sama lainnya. Memberikan pertolongan sama dengan memberikan kasih sayang, karena kasih sayang merupakan sikap mengasihi terhadap diri sendiri, orang lain dan sesama makhluk. Masyarakat Desa Maringgai masih menerapkan sikap saling tolong menolong kepada sesama, bila ada salah satua anggota masyaraatnya yang mengadakan acara ataupun kerjabakti. Masyarakat datang tanpa ada yang memerintah, memberi sumbangan materi tanpa ada yang meminta dan berempati terhadap saudara yang terekena musibah. Menjaga dan melestarikan suatu kebudayaan pada suatu masyarakat bukanlah hal yang mudah, maka salah satu cara untuk teteap dapat melestarikannya adalah dengan mempraktikan dalam kehidupan sehari-hari. Hal inipun telah dilakukan oleh masyarakat Desa Maringgai dalam melestarikan Falsafah Pi'il Pesenggiri dan semua unsurunsurnya. Adapun kegiatandari Pi'il Pesenggiri di Desa Maringgai adalah melalui kegiatan acara Perkawinan, Bertamu, Menjauw, Pengajian, Musyawarah dan Kerjabakti atau gotong royong.

\section{KESIMPULAN}

Dari uraian pembahasan diatas maka dapat disumpukan bahwa Nilainilai Islam yang ada pada falsafah hidup Pi'il Pesenggiri dan model unsur-unsur implementasinya yaitu sebagai berikut: Juluk adek nilai kepemimpinan. Nemui nyimah terdapat nilai silaturahim, nilai sopan santun. Nengah Nyappur terdapat nilaisosial dan nilai intelektual. Dan Sakai Sambaian terdapat nilai gotong-royong, nilaita'wun, dan nilai saling menghormati. Kemudian, Implementasi 
Falsafah Hidup Pi'il Pesenggiri dan keempat unsurnya di Desa Maringgai masih diterapkan, hal ini dapat dilihat dalam acaraadat perkawinan, kegiatan bertamu dalam sehari-hari, menjau, pengajian, serta membersihkan jalan dan masjid.

\section{DAFTAR PUSTAKA}

A. Daliman, Islamisasi dan Perkembangan Kerajaankerajaan Islam di Indonesia, Yogyakarta: Ombak.

Agus Joko Pitoyo, Hari Tri Wahyudi, Dinamika Perkembangan Etnis di Indonesia dalam Konteks Persatuan Negara, Yogyakarta: Fakultas Geografi UGM Vol. 25 No. 1, 2017

Deden Sumpena, Islam dan Budaya Lokal: Kajian Terhadap Interelasi Islam dan Budaya Sunda, Bandung: UIN Sunan Gunung Djati, Jurnal Ilmu Dakwah Vol. 6 No. 19

Departemen RI, Al-Quran dan Terjemahannya, Jakarta: PUSTAKA AL-FATIH, 2009

Fachruddin, Dkk, Upacara Cangget Agung Aktualisasi Nilai-nilai Budaya Daerah Lampung Bagi Generasi Muda, Lampung: CV Prinsip Bandar Lampung, 1999

Firman Sujadi, Lampung Sai Bumi Ruwa Jurai, Jakarta: Cita Insan Madani, 2013

Himyari Yusuf, Nilai-nilai Islam dalam Falsafah Hidup Masyarakat Lampung, Jurnal Studi Agama dan Pemikiran Islam IAIN Raden Intan Lampung Vol. 10 Nomor 1 Juni 2016

Kemenag RI, Pedoman Penulisan Karyallmiah dan Skripsi, Palembang: Kopertais 